\title{
THE EFFECT OF GIVING INCENTIVES TO EMPLOYEE PERFORMANCE PT. BPR EKADHARMA MAGETAN
}

\author{
Wahna Widhianingrum \\ Faculty of Economics Muhammadiyah Ponorogo University \\ Email:wwahna@yahoo.com
}

\begin{abstract}
The problem in this study is whether the provision of incentives significantly affects the performance of employees at PT. BPR Ekadharma Magetan. The purpose of this study is to determine whether there is an effect of giving incentives to employee performance. The type of research used is quantitative with an associative approach. The technique of collecting data through observation, questionnaires and documentation. While the data analysis technique used is simple linear regression. As for the types of data sources, this research is primary data, namely data obtained directly from the source or place where the research was conducted. The population of this research is all employees and managers of PT. BPR Ekadharma Magetan totaling 93 people. The sample determination is saturated sampling. Data obtained using SPSS 21 (Statistical Product and Service Solutions). The results of this study indicate that based on the results of research that researchers conducted at PT. BPR Ekadharma Magetan that giving incentives has a significant effect on employee performance. This can be seen from the results of statistical calculations through partial hypothesis testing which shows that $\mathrm{t}$ count $>\mathrm{t}$ table then Ha is accepted and Ho is rejected.
\end{abstract}

Keywords: Incentives, Employee Performance.

\section{Introduction}

Human resource management is one area of management that specializes in studying human relationships and roles in organizations. This is because human resource management regulates the workforce in the organization so that organizational goals and job satisfaction are realized. Human resource management can also produce good performance in a company by assessing, giving rewards in each individual member of the organization in accordance with their ability to work.

Performance is the real behavior that is displayed by everyone as the work performance produced by employees in accordance with their role in the company. Employee performance is a very important thing in the company's efforts to achieve goals.

One way to optimize employee performance is by giving rewards (incentives) inadvertently given to employees so that in them a greater enthusiasm arises to improve work performance so that productivity and performance increase. Providing incentives in a company plays an important role because it is believed to be able to overcome various problems in the workplace that are increasingly complex, such as low performance due to employee enthusiasm and enthusiasm, which can still be caused by lack of work motivation, employee status (not employees) fixed) and there is no additional income for employees other than salary. For companies, the 
International Journal of Economics, Business and Accounting Research (IJEBAR)

Peer Reviewed - International Journal

Vol-2, Issue-4, 2018 (IJEBAR)

ISSN: $2614-1280$

http://www.jurnal.stie-aas/ijebar

provision of incentives is expected to improve employee performance, work productivity, loyalty, discipline, a sense of responsibility for office and the better quality of leadership for employees; with the provision of incentives they get the opportunity to increase income.

Thus, it can be argued that incentives (incentive) are elements of income or remuneration that are given in an irregular or variable manner depending on the conditions of employee achievement. From the theory stated that the incentive is the provision of money outside the salary that employees should receive given by the company's management in recognition of the performance of employees to the company. So the greater the contribution of an employee to the company, the greater the company should give as a reward to employees.

PT. BPR Ekadharma is a People's Credit Bank that stands in Magetan Regency. In addition to building competence in the banking sector, Ekadharma also gives special attention to the development of human resources to be more productive in improving banking performance.

PT. BPR Ekadharma provides incentives to every employee both in any field as a whole or can be said to be global but the division is seen from the position held by each employee. If the position held by an employee is high then the incentives received are also large so that they are motivated by this incentive, so they will be even more enthusiastic in processing their performance by doing their best so that they can work better.

Based on the explanation above, the authors are interested in carrying out research on employee performance. Based on the description, the title of the Effect of Giving Incentives on Employee Performance at PT. BPR Ekadharma.

\section{Literature Review}

\subsection{Incentive}

Incentives are remuneration provided by companies that can be valued with money and have a tendency to be given regularly. Incentives are defined as forms of payment associated with performance and gain sharing, as sharing benefits for employees due to increased productivity or cost savings (Burhanuddin, 2015).

This system is another form of compensation directly outside salaries and wages which is fixed compensation, which is called a compensation system based on performance (pay for performance plan). Incentives are a driving factor for employees to work better so that employee performance can increase. Compensation and incentives have a very close relationship, where incentives are a component of compensation and both are crucial in achieving the overall goals and objectives of the organization.

The purpose of providing incentives is to fulfill the interests of parties, namely:

a. For companies:

1) Maintaining a skilled and capable workforce so that loyalty is high for the company

2) Maintain and improve employee morale that is shown to be a decrease in the level of labor turnover and attendance

b. For employees:

1) Increase the standard of living with receipt of payments outside the basic salary

2) Increase employee work motivation so as to encourage them to perform better.

Some forms of incentives that can be given to employees, namely (Rivai, 2005):

a. Yearly bonus

Many companies replace employee income based on services by providing annual, semi-annual or quarterly 
International Journal of Economics, Business and Accounting Research (IJEBAR)

Peer Reviewed - International Journal

Vol-2, Issue-4, 2018 (IJEBAR)

ISSN: $2614-1280$

http://www.jurnal.stie-aas/ijebar

performance bonuses. Generally this bonus is shared more often once a year. Bonuses have some advantages incurred by increasing salaries. First, bonuses increase the meaning of payments because they receive large amounts of wages. Second, bonuses maximize the relationship between pay and performance.

b. Direct incentives

Unlike other payment systems based on performance, direct bonuses are not based on formulas, special criteria, or goals. This reward for performance which is sometimes called lightning is designed to recognize the contribution of outside employees. Often the award is in the form of certificates, placards, cash or bouquets of flowers.

c. Individual incentives

Individual incentives are a form of old and most popular incentive payments. In this type, individual performance standards are established and communicated beforehand, and rewards are based on individual output.

d. Team incentives

Team incentives are among individual programs and entire organization programs such as revenue sharing and profit sharing. Team incentives connect individual goals with group goals.

e. Profit sharing

The profit sharing program is divided into three categories. First, distribution programs now provide percentages to be shared quarterly or annually for employees. Second, deferred distribution programs place income in a destination fund for retirement, termination, death or disability. Third, a joint program that shares part of the profits directly with employees, and sets aside the remainder in the specified account.

\subsection{Performance}

In the large Indonesian dictionary (Hoetomo, 2005) performance is something that can be achieved. Performance comes from the word job performance or actual performance, which means work performance or actual achievement achieved by someone. Performance reflects how far the success of a job has been achieved. Furthermore, human performance is a function and level of ability, attitude, and degree of motivation. Performance is behavior real that is displayed by everyone, as work performance produced by employees in accordance with their role in the company.

According to Suyadi Prawirosentono (1999) performance is the result of work that can be achieved by a person or group of people in the organization in accordance with the authority and responsibility of each in order to achieve the objectives of the relevant organization legally, not violating the law and in accordance with morals and ethics. While the performance in human resource management books written by Robert L. Mathis and Jhon H. Jackson (2002) also explained that performance is basically what is done or done by employees.

According to Mangkunegara (2002) argues that the performance results in quality and quantity achieved by an employee in carrying out his duties in accordance with the responsibilities given to him. Performance is a real behavior that is displayed by everyone as work performance produced by employees in accordance with their role in the company. Besides being able to be used as a standard in determining the level of compensation and administration for employees, performance appraisal is carried out with the following objectives:

a. Increase mutual understanding between employees about performance requirements

b. Record and acknowledge the work of an employee, so that they are motivated to 
do better or at least achieve the same as previous achievements.

c. Providing opportunities for employees to discuss their desires and aspirations and increase awareness of their current career or job.

d. define or reformulate future goals, so that they are motivated to achieve according to their potential.

e. Examine the implementation and development plans that are appropriate to the training needs, specifically the training plan, and then approve the plan if there are no things that need to be changed.

The benefits of performance appraisal are as follows:

a. Performance improvements provide opportunities for employees to take corrective actions to improve through the feedback provided by the company.

b. Salary adjustments can be used as information to compensate employees properly so they can motivate them.

c. Decision for placement, which can be done by the placement of employees according to their expertise.

d. Training and development, through assessment of the weaknesses of employees so that a more effective compliance and development program can be carried out.

e. Career planning, which can provide career planning assistance for employees and align with the interests of the organization.

f. Identify weaknesses in the placement process, ie poor performance shows weaknesses in placement so that improvements can be made.

g. Can help employees overcome problems that are external, that is, with the value of superior performance, they will know what causes bad performance, so that the boss can help solve it.

The factors that influence a person's performance are (Prabu Mangkunegara, 2002):

a. The ability factor, in general this ability is divided into 2 namely potential ability (IQ) and reality ability (knowledge and skill).

b. Motivational factors, motivation is shaped by the attitude of employees in dealing with work situations. Motivation for employees is very important to achieve the company's vision and mission.

There are seven performance indicators. Two of them have very important roles, namely goals and motives. Performance is determined by the goals to be achieved and to do so a motive is needed. Without motives to achieve goals, performance will not work. Thus goals and motives are the main indicators of performance. The indicators are as follows: (Wibowo, 2014)

a. Objective: A goal is something better that you want to achieve in the future. Thus, the purpose of showing the direction in which performance should be carried out. On this basis, performance is carried out to achieve the goal. To achieve goals, the performance of individuals, groups and organizations is needed. Individual and organizational performance is successful if it can achieve the desired goals.

b. Standard: Standard is a measure of whether the desired goal can be achieved. Without standards, it cannot be known when a goal is reached. Standards answer questions when we know that we are successful or failed. A person's performance is said to be successful if it is able to reach a standard determined or agreed upon between superiors and subordinates.

c. Feedback: Feedback is an input used to measure performance progress, performance standards, and achievement 
International Journal of Economics, Business and Accounting Research (IJEBAR)

Peer Reviewed - International Journal

Vol-2, Issue-4, 2018 (IJEBAR)

ISSN: $2614-1280$

http://www.jurnal.stie-aas/ijebar

of goals. With feedback an evaluation of performance is carried out and as a result performance improvements can be made.

d. Tools or Facilities: Tools or facilities are resources that can be used to help complete goals successfully. Tools or facilities are supporting factors for achieving goals. Without tools or facilities, specific work tasks cannot be carried out and objectives cannot be resolved as they should. Without a tool it is impossible to do work.

e. Competence: Competence is the ability possessed by someone to carry out the work given to him well.

f. Motive: Motives are a reason or driver for someone to do something. Managers facilitate motivation to employees with monetary incentives, give recognition, give freedom to do work including time to do work, provide necessary resources and eliminate actions that result in disintense.

g. Opportunity: Workers need to get the opportunity to show their work performance. There are two factors that contribute to the lack of opportunities for achievement, namely the availability of time and the ability to fulfill the requirements.

\section{Research Methods}

The location of the study took place at PT. BPR Ekadharma Magetan Regency. The research approach used in this study is to use descriptive analysis with a quantitative approach and assisted with the SPSS program, this type of research is to obtain accurate information about incentives provided by the company to employees through performance evaluation by distributing questionnaires to employees to obtain data Accurate.

The formula for the regression equation is:
$\mathrm{Y}=\mathrm{a}+\mathrm{bX}+\mathrm{e}$

Information :

Y: Performance Variables

$\mathrm{X}$ : Incentive variable

a: Constants

b: Regression coefficient

e: other variables not examined

\section{Results and Discussion}

This study describes the effect of giving incentives to the performance of employees at PT. BPR Ekadharma Magetan. This aims to determine how much influence the incentives on employee performance at PT. BPR Ekadharma Magetan. In this study, researchers used 93 employees as the research sample.

The validity test used is scale analysis which looks at the total item-statistical table and in the corrected item- Total Correlation column then compared to $\mathrm{r}$ table $(5 \%)$. It is valid if the value of the correlation item Total Correlation> $r$ table $=0.204$. The results of the validity test show that all the calculated values are greater than r-table (0.204), meaning that each question correlates with the total score the data collected is declared valid and ready for analysis.

Reliability testing is used to measure an instrument to what extent the instrument can be trusted. Testing with Cronbach's Alpha is used to test the level of confidence of each variable questionnaire.

The reliability measurement method used is the Alpha Cronbach $(\alpha)$ method. The Cronbach Alpha coefficient shows the extent of the respondents' consistency in answering the instrument being assessed. A reliable indicator if the Cronbach Alpha value is greater than 0.6057. From Cronbach Alpha for all items amounting to 0.822 values more than 0.60 , it can be concluded that the research instrument has been reliable or in other words acceptable. 
International Journal of Economics, Business and Accounting Research (IJEBAR)

Peer Reviewed - International Journal

Vol-2, Issue-4, 2018 (IJEBAR)

ISSN: $2614-1280$

http://www.jurnal.stie-aas/ijebar

Simple linear regression analysis is a linear relationship between one independent variable $(\mathrm{X})$ and the dependent variable $(\mathrm{Y})$. This analysis is to determine the direction of the relationship between the independent variable and the dependent variable whether positive or negative and to predict the value of the dependent variable if the value of the independent variable increases or decreases. The results of a simple regression analysis can be seen in the following table.

Table 4.13

Simple Regression Test Results

Coefficients

\begin{tabular}{|c|c|c|c|c|c|c|}
\hline \multirow{2}{*}{\multicolumn{2}{|c|}{ Model }} & \multicolumn{2}{|c|}{$\begin{array}{c}\text { Unstandardized } \\
\text { Coefficients }\end{array}$} & \multirow{2}{*}{$\begin{array}{c}\begin{array}{c}\text { Standardized } \\
\text { Coefficients }\end{array} \\
\text { Beta }\end{array}$} & \multirow[t]{2}{*}{$\mathrm{t}$} & \multirow[t]{2}{*}{ Sig. } \\
\hline & & B & Std. Error & & & \\
\hline \multirow[t]{2}{*}{1} & (Constant) & 30.804 & 4.000 & \multirow[b]{2}{*}{.224} & 7.702 & .000 \\
\hline & Incentive & .218 & .100 & & 2.190 & .031 \\
\hline
\end{tabular}

Source: Processed Primary Data SPSS 21, 2018

Based on the table, the regression equation is obtained as follows: $\mathrm{Y}=30,804+$ $0.218 \mathrm{X}$. The regression equation can be explained as follows:

$\alpha=30,804$ is a constant value, indicating that if the incentive is 0 , then the employee's performance is 30,804 $\mathrm{b}=0.218$ is the coefficient value indicating that each incentive increase is 1 point, then employee performance will increase by 0.218

To find out the strength of the relationship between variables $\mathrm{X}$ and $\mathrm{Y}$ can be seen in the table below:

Table 4.14 Correlation Coefficient Test

\begin{tabular}{|l|l|r|r|}
\hline \multicolumn{2}{|l|}{} & \multicolumn{1}{|c|}{ Incentive } & Performance \\
\hline & Pearson Correlation & 1 & $.224^{*}$ \\
\hline Incentive & Sig. (1-tailed) & & .016 \\
\hline & $\mathrm{N}$ & 93 & 93 \\
\hline & Pearson Correlation & $.224^{*}$ & 1 \\
\hline Performance & Sig. (1-tailed) & .016 & \\
\hline & $\mathrm{N}$ & 93 & 93 \\
\hline
\end{tabular}

*. Correlation is significant at the 0.05 level (1-tailed).

Source: Processed Primary Data SPSS 21, 2018 
International Journal of Economics, Business and Accounting Research (IJEBAR)

Peer Reviewed - International Journal

Vol-2, Issue-4, 2018 (IJEBAR)

ISSN: $2614-1280$

http://www.jurnal.stie-aas/ijebar

At the output above, it can be seen that the correlation between giving incentives to employee performance produces a number 0.224 and a sig (1-tailed) value of 0.016 . This number shows a number below or smaller than 0.05 , then the correlation value is positively (+) and significant. This shows that the relationship is in the same direction, which means that if incentives are given to employees effectively then employee performance will increase. Vice versa.

The terminated coefficient is used to calculate how much the contribution or contribution of variable $\mathrm{X}$ to variable $\mathrm{Y}$, or in other words to calculate the magnitude of the effect of giving incentives to employee performance. The coefficient of determination can be seen in the table below:

Table 4.15 Determination Coefficient test results

\begin{tabular}{|l|l|r|r|r|}
\multicolumn{7}{|c|}{ Model Summary } \\
\hline Model & $\mathrm{R}$ & R Square & $\begin{array}{c}\text { Adjusted R } \\
\text { Square }\end{array}$ & $\begin{array}{l}\text { Std. Error of } \\
\text { the Estimate }\end{array}$ \\
\hline 1 & $.224^{\mathrm{a}}$ & .050 & .040 & 2.89907 \\
\hline \multicolumn{5}{|c|}{ Source: Processed Primary Data SPSS 21, 2018} \\
\hline
\end{tabular}

From the results of processing it can be seen that the contribution or contribution of incentives to performance is $5 \%$ while the remaining $95 \%$ is influenced by other factors not found in this study. The reason why $R$ has a very low effect is because incentives are only given to certain employees whose performance exceeds the standards set by the company, besides, regular monthly salary payments to employees affect the low $\mathrm{R}$. Then on R2 (Square) it is very low because in in this company only provides incentives at the end of the year, besides that many other factors that affect mainly are the provision of basic salaries of employees, work experience, level of education, employee loyalty and so forth.

To determine the effect of the incentive variable (X) on employee performance variables (Y), with the following hypothesis:

Ho: There is no significant influence between providing incentives with employee performance

Ha: There is a significant influence between giving incentives and employee performance.

Decision criteria: If $\mathrm{t}$ count $<\mathrm{t}$ table then Ho is accepted, at $\alpha=5 \%$ If $t$ count $>\mathrm{t}$ table then $\mathrm{Ha}$ is accepted, at $\alpha=5 \%$

Based on the results of calculations obtained $t$ count of 2.190 , with degrees of freedom $(\mathrm{df})=\mathrm{n}-2$. Then the $\mathrm{t}$ table is 1986 . Because $t$ count $>t$ table with a significant level in the table of 0.031 which means 0.031 $<0.05$ then $\mathrm{Ho}$ is rejected and $\mathrm{Ha}$ accepted means that it can be seen that the provision of incentives significantly affects the performance of employees at PT. BPR Ekadharma Magetan at the standard level the coefficient is 0.224 or $22.4 \%$.

After making observations using questionnaires as data collection media which were then analyzed using linear regression test using SPSS version 21. The purpose of the analysis was to determine 
International Journal of Economics, Business and Accounting Research (IJEBAR)

Peer Reviewed - International Journal

Vol-2, Issue-4, 2018 (IJEBAR)

ISSN: $2614-1280$

http://www.jurnal.stie-aas/ijebar

whether or not there was a significant effect of giving incentives to employee performance at PT. BPR Ekadharma Magetan.

Thus the coefficient of incentive variable $(\mathrm{X})$ is obtained as 0.218 while the constant is 30,804 so that the regression equation can be obtained as follows $\mathrm{Y}=$ $30,804+0.218 \mathrm{X}$. Based on the results of these calculations, it can be seen that there is a significant effect of the independent variable $(\mathrm{X})$ on the variable dependent $(\mathrm{Y})$ seen in the hypothesis proposed by the author stated that:

Ho: there is no influence between giving incentives to employee performance

$\mathrm{Ha}$ : there is an influence between giving incentives to employee performance.

Then obtained a significant value of 0.031 , while the alpha value used is 0.05 or $5 \%$ means $0.031<0.050$, then Ho is rejected and $\mathrm{Ha}$ is accepted. This means that there is an influence between the variable incentives (X) on employee performance (Y). The results of this study are in line with the research conducted by Widyatama with the research title "The Effect of Incentives on Increasing Employee Performance in the Marketing Operations Department at the Jakarta Arterial Branch of Dunkin Donuts" which explains that incentives have a positive and significant effect on employee performance. Incentives contain a professional relationship where one of the goals of employees working is to get rewards for fulfilling various needs, while at the company side they provide incentives so that employees can carry out work in accordance with the wishes and expectations of the company with the main goal of being able to advance the company's business.

The results of this study are supported by the theory of Hani Handoko who said that incentives are generally used to describe wage payment plans that are directly or indirectly associated with various standards of employee productivity / performance or organizational profitability or both of these criteria. Therefore, employees who work under an incentive system mean their work performance determines, in whole or in part their proposed income.

Incentive programs pay an individual or group for what exactly they produce. Here can be seen by giving incentives that are more feasible and accepted by employees because in accordance with the energy and capabilities that are issued and appreciate the hard work of employees, the employees will be more professional by working seriously and making various efforts to achieve more work good so that performance can be improved. With good performance will certainly advance the course of the company.

\section{Conclusion}

Research on the Effect of Providing Incentives on Employee Performance at PT. BPR Ekadharma Magetan produces conclusions based on the analysis that Giving Incentives influences Employee Performance at PT. BPR Ekadharma Magetan. The results of the analysis show that giving incentives has a positive and significant effect on employee performance at PT. BPR Ekadharma Magetan. 
International Journal of Economics, Business and Accounting Research (IJEBAR)

Peer Reviewed - International Journal

Vol-2, Issue-4, 2018 (IJEBAR)

ISSN: $2614-1280$

http://www.jurnal.stie-aas/ijebar

\section{Reference}

Handoko, H. 1995. Personal Management and Human Resources. Yogyakarta: Liberty.

Hoetomo. 2005. Large Dictionary of Indonesian Language. Surabaya: Student Partners.

Rivai, Vl. 2005. Human Resource Management. Jakarta: Raja Grafindo Persada.

PT Remaja Rosdakarya.

Mathis, L.R \& Jhon H.J. (2002). Human Resource Management: Business, Management, Finance, and HR. Jakarta: Salemba Empat.

Wibowo. 2014. Work Management. Jakarta: Rajawali Press.

Widyatama.http:

//repository.widyatama.ac.id/xmlui/bitstr eam/handle/123456789/272/Bab\%202.

Mangkunegara, P. 2002. Company Human Resource Management. cet. 2; Bandung:

Yusuf, B. 2015. Human Resource Management in Islamic Financial Institutions. Cet. 1, Jakarta:

Rajawali

Press. 